\title{
Farmers' Perception of the Effects of Climate Change and Coping Strategies in Three Agro-Ecological Zones of Nigeria
}

\author{
Tologbonse, E.B*; Auta,S.J; Bidoli, T.D ; Jaliya M.M; Onu, R.O and Issa F.O \\ National Agricultural Extension \& Research Liaison Services, \\ Ahmadu Bello University, Zaria. \\ *E-mail: deletologbonse@yahoo.com ; Mobile:+23480-3642-6505
}

\begin{abstract}
The study assessed farmers perception of the effects of climate change and coping strategies in three agro-ecological zones of Nigeria. Three agro-ecological zones namely Middle-Belt, North-Central and North-East were purposively selected and one LGA where NAERLS extension model village is located was purposively selected from each of the 3 agro-ecological zones. One village was randomly selected in addition to the NAERLS model village. Twenty five farmers were randomly selected from each village. One hundred and fifty (150) validated structured questionnaires were used to elicit information from respondents. Data were analysed using both descriptive and inferential statistics. Farmers were fully aware of the effect of climate change and possible coping strategies such as the need for agricultural insurance, planting of drought and flood tolerant varieties and reduction of water loss through practices such as mulching and rearing of heat tolerant livestock. General perception was that climate change increases the rate of sickness/infection, reduces family income and that frequency of flood and that drought has increased. Chi-square analysis indicated a positive and significant relationship between perception of climate change and agro-ecology $\left(X^{2}=23.52\right.$; $p<0.05)$, age $\left(X^{2}=5.98 ; p<0.05\right)$, educational level $\left(X^{2}=6.47 ; p<0.05\right)$, coping strategy $\left(X^{2}=23.29 ; p<0.05\right)$ and $\operatorname{communities}\left(X^{2}=37.36 ; p<0.05\right)$. It was recommended that efforts should be geared towards developing and making available crop varieties and livestock breeds that are tolerant to adverse conditions associated to climate change such as diseases, flood, drought and temperature. A multi-media enlightenment campaign of the effects and possible coping strategies of climate change should be adopted by all tiers of government and NGOs to reach the farmers using available extension structure on ground. Also, farming communities can run local disaster risk committees to encourage local adaptation measures as survival tactics for the purpose of ensuring food security.
\end{abstract}

Keywords: Farmers Perception, Coping strategies, Climate Change, Agro-ecological Zones, Nigeria.

\section{Introduction}

Climate change is a major challenge to agricultural development in Africa and the world at large. It is not only a challenge to agricultural development but to food security and the general livelihood conditions of any population. Agriculture, being one of the most weather-dependent of all human activities is highly vulnerable to climate change. African countries are particularly vulnerable to climate change because of their dependence on rain fed agriculture, high levels of poverty, low levels of human and physical capital, inequitable land distribution and poor infrastructure (Watson et al., 1997). Africa, like the rest of the world, is experiencing 
increasing risk from climate change, including rising temperatures and heat waves, shortfalls in water supply/increasing floods arising from shortage/excessive rainfalls, sea level rise, increasing likelihood of conflict and induced environmental and vector borne diseases. These conditions emanating from climate change are bound to compromise agricultural production (crop, livestock, forest and fishery resources), nutritional and health statuses, trading in agricultural commodities, human settlements (especially of agricultural communities), tourism and recreation among others.

Generally, climate change is expected to have a mixed effect on agriculture with some areas benefiting from moderate temperature increases and others being negatively affected. Positive effects of climate change could arise from changes in seasons and production cycles. For example, Ethiopia and Southern Africa are expected to have extended growing seasons as a consequence of increased temperature and rainfall. In the same vein, livestock production could be boosted by temperature increases (FAO, 2009). Conversely, Deressa and Hassan (2009) found increasing temperatures to be particularly damaging to Ethiopian agriculture, a situation that is not uniformly distributed across agro-ecological zones. Kurukulsuriya and Mendelson (2007) equally indicated that African agriculture is sensitive to climate change in the sense that farmers will experience net revenue losses from warming, especially with reduction in precipitation. Also, climate change is thought to be responsible for conflict in Darfur where a combination of decades of drought, desertification and overpopulation are among the causes of conflict in that the Baggara Arab nomads in search of water have to take their livestock further south, to lands mainly occupied by farming peoples ( IFPRI, 2009).

The above effects of climate change can be said to hold true for Nigeria in the sense that the same ecological conditions apply especially in the savanna and sahelian regions of the north. Along the coastal regions of the south however, the situation is significantly different from that of the north. Specifically, evidence of climate change in Nigeria is observed to involve the drying up of lakes and natural ponds (e.g Lake Chad) within a period of less than 30 years. This has resulted in environmental refugees, biodiversity loss, disappearance of some species of flora and fauna and restriction of most small rivers and streams which are active only at mid-rainy seasons. Other aspects of climate change manifestations includes reduced period of Hamattan season to barely 2 months between December - January as opposed to November - March, the encroachment of the Sahara desert at the rate of over one kilometer per annum, flooding of coastlines, low crop yield and increased conflicts between farmers and herdsmen (Sambo 2010). Awosika et al (1992) observed that for a rising sea level, inundation could occur along more than $70 \%$ of the Nigerian coastline, thus placing land at risk many kilometers inland. A one meter rise in sea level for example, could place up to $600 \mathrm{~km}^{2}$ of land at risk. They equally predicted that the rates of land loss through edge erosion alone could cause losses of as much as $250 \mathrm{~km}^{2}$ by the year 2100 .

With this condition, they foresee a potentially massive environmental refugee migration occurring in Nigeria. For a one meter rise, more than 3 million people are at risk based on the population at the time. Estimates of the number of people to be displaced ranges from 740,000 for a 0.2 meter rise to 3.7 million for a 1 meter rise and 10 million for a 2 meter rise. CTA (2009) observed that climate change has led to a reduction in livelihood options in many African, Carribean and Pacific (ACP) countries. For instance, demographic shifts within rural societies, low level of 
education and poorly developed communication and market infrastructure is seen as complicating the task of developing location-specific response that effectively addresses the issue. It further highlighted the importance of facilitating communication among and between various actors to contribute to the effectiveness of intervention strategies.

Coping with climate change in generally requires support for mitigation and adaptation for low carbon cleaner energy. Apart from the fact that Africa is the hardest hit continent by climate change, it has the weakest coping capacity and the resources to help manage disaster risk and adaptation to climate change are limited and segmented in most African countries including Nigeria. In Nigeria, limited action to reduce deforestation constitutes a major challenge. Other Challenges includes reduced agricultural production, worsened food security, increased incidence of both flooding and drought, spreading disease and an increased risk of conflict over scarce land and water resources.

It is believed that mitigating strategies to combat the effects of climate change and also ensuring improved and sustainable livelihood for the farm family depends on the knowledge, attitudes, practices and belief systems of farmers. Farmers' perception, belief and management strategies of Climate change need to be documented for they are thought to influence the success of management practices compared to other factors. Gaps probably exist in farmers' indigenous knowledge of their understanding of effect and coping strategy of climate change Therefore studies of farmers' knowledge of Climate change should be appraised and their perception as well as identify gaps in their knowledge and areas where scientists and other stakeholders including extension agents could provide vital inputs to assist farmers. Thus the need for this research to assess the perceptions of this important group of stakeholders in the agricultural development system.

The general objective of the study was to determine the farmers perception of the effects of climate change and coping strategies in three agro ecological zones of Nigeria.

The specific objectives were to:

i. describe the socioeconomic characteristics of farmers;

ii. determine farmers sources of awareness of climate change and when they started noticing the change;

iii. determine farmers perception of effect of climate change;

iv. ascertain farmers' perception of coping strategies in reducing/alleviating the effect of climate change; and

v. determine the relationship between the perception of effects of climate change and other independent variables

\section{Methodology}

The target population was made up of all the farmers in the agro-ecological zones in Nigeria. Three out of 5 agro-ecological zones were purposively selected. From each zone, one State where NAERLS zonal office is located was also selected, namely Niger, Kaduna and Borno. In each of these States, one local government area (LGA) where the NAERLS Adopted extension village is located was purposively selected. In each of the selected LGA, the NAERLS Adopted extension village community was also purposively selected and a second village in the LGA was randomly selected making a total of 2 communities per zone. Twenty five farmers were randomly selected from each of the villages resulting in a total of 
50 respondents from each agro-ecological zone and a total sample size of 150 respondents. Validated structured interview schedule were used to obtain primary data from the respondents with the assitance of trained enumerators that understood the local language. Data collected were subjected to both descriptive and inferential statistics. The descriptive statistics involved frequency counts, mean and percentage. The inferential statistics invovled the use Chi square. A 4-point likerttype scale of strongly agree, agree, dis-agree and strongly disagree of which was assigned weights of $4,3,2,1$, respectively was used to investigate and measure the effect of climate change and climate change coping strategies.

In calculating perception of effect of climate change (PCC) and climate change coping strategies (CCCS), the mid-point values of the scale were summed and further divided by 4 to obtain mean of 2.5. The mean for each of the PCC and CCCS was obtained by multiplying the point scale by the number of respondents in each point scale. Any PCC or CCCS with a mean score of equal or above the cut-off mean of 2.5 was regarded and perceived as 'agree' and any mean score of lower than 2.5 was perceived as 'do not agree'

Furthermore, PCC and CCCS scores were obtained by adding the score of each respondent for each of the PCC and CCCP. The maximum score obtainable was 112 and 36 for PCC and CCCS respectively. The score obtained for each respondent was further dichotomised into low and high perception based on the mean score in each case. This was used to determine the relationship between the dependent variable, PCC and other independent variables.

\section{Results and Discussion \\ Socio-economic characteristics}

As indicated in Table 1,95.3\% of farmers were males and $4.7 \%$ were females. Majority ( $82 \%)$ of the farmers were of the active productive age bracket (3150 years). With regard to educational level, $72.1 \%$ of farmers had low level as against $27.9 \%$ having high level. About $83 \%$ of farmers had more than 10 years of farming experience. Likewise, $77.9 \%$ of farmers were found to be members of farmers' cooperative associations. It is expected that farmers' age, level of education, farming experience and membership of cooperatives, would influence their perception of the effects of climate change in agriculture. 
Table 1 : Socio-economic Characteristics of Respondents

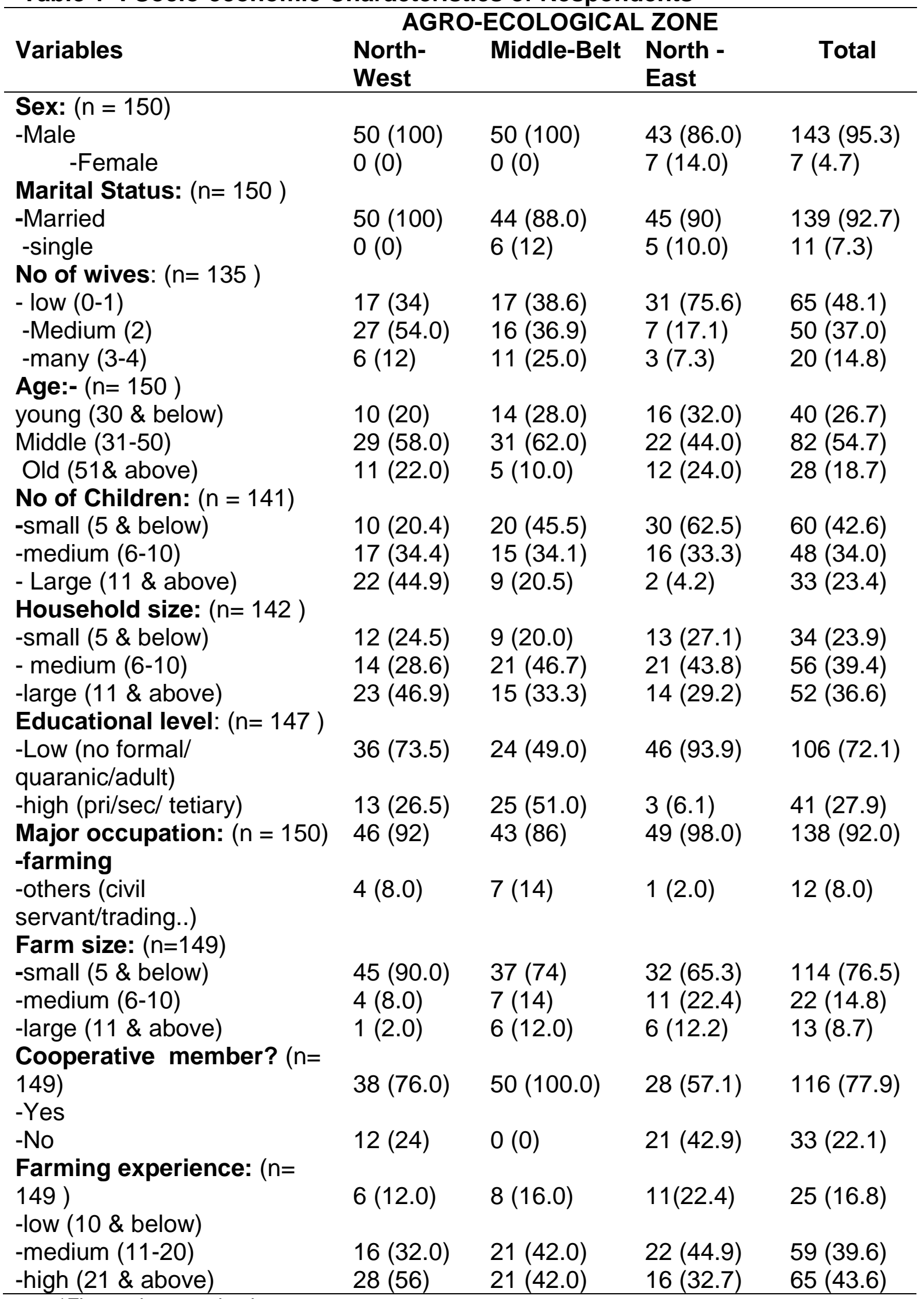

${ }^{*}$ Figures in parenthesis are percentages 


\section{Perception of the Effects of Climate Change}

About $67 \%$ of the respondents strongly agree that climate change (CC) resulted in increase in temperature. About $55 \%$ strongly agreed that climate change reduces yield of crops generally and $53 \%$ agree that some crops are more prone to climate change than others. Majority (61\%) of the respondents stronghly agree that climate change increases poverty rate of farmers generally. The weighted mean reveals that the respondents were of the general opinion that climate change did not increase their income (2.29) neither did it decrease the rate of sickness (2.14) but that it inceased the rate of sickness/infection and reduces family income (3.03). Farmers agreed that the frequency of flood (2.88) and drought (3.18) had increased because of the climate change. This may tend to suggest that farmers are aware that the effect of climate change has indeed led to increase in flooding, drought and rate of sickness/infection. 
Table 2 : Perception of Effects of Climate Change

\begin{tabular}{|c|c|c|c|c|c|c|c|}
\hline Possible Effects & $\begin{array}{l}\text { Strongly } \\
\text { agree }\end{array}$ & Agree & $\begin{array}{l}\text { Dis- } \\
\text { agree }\end{array}$ & $\begin{array}{l}\text { Strongly } \\
\text { disagree }\end{array}$ & $\begin{array}{l}\text { Weighted } \\
\text { sum }\end{array}$ & $\begin{array}{l}\text { Weidgted } \\
\text { mean }\end{array}$ & $\begin{array}{l}\text { Overall } \\
\text { percepti } \\
\text { on }\end{array}$ \\
\hline Increase in temperature $(n=149)$ & $101(67.8)$ & $46(30.9)$ & $1(0.7)$ & $1(0.7)$ & 545 & 3.66 & agree \\
\hline $\begin{array}{l}\text { Drastic change in weather generally } \\
(n=149)\end{array}$ & $90(60.4)$ & $52(34.9)$ & $3(2.0)$ & $4(2.7)$ & 526 & 3.53 & agree \\
\hline Reduces yield of crops generally $(n=148$ ) & $82(55.4)$ & $48(32.4)$ & $6(4.0)$ & $12(8.1)$ & 496 & 3.35 & agree \\
\hline Increases yield of crops generally $(n=146)$ & $30(20.0)$ & $31(20.7)$ & $63(42.0)$ & $22(15.1)$ & 361 & 2.47 & $\begin{array}{l}\text { Do not } \\
\text { agree }\end{array}$ \\
\hline $\begin{array}{l}\text { Some crops more prone to climate change } \\
\text { than others }(n=148)\end{array}$ & $44(29.7)$ & $78(52.7)$ & $21(14.0)$ & $4(2.7)$ & 456 & 3.10 & agree \\
\hline $\begin{array}{l}\text { Increases productivity of livestock } \\
\text { generally }(n=146)\end{array}$ & $42(28.6)$ & $15(10.2)$ & $76(51.7)$ & $13(8.9)$ & 378 & 2.59 & agree \\
\hline $\begin{array}{l}\text { Reduces productivity of livestock generally } \\
(n=149)\end{array}$ & $36(24.2)$ & $64(43.0$ & $30(20.1)$ & $19(12.8)$ & 415 & 2.79 & agree \\
\hline $\begin{array}{l}\text { Some livestock more prone to climate } \\
\text { change than others }(n=144)\end{array}$ & $49(33.3)$ & $64(43.8)$ & $24(16.4)$ & $7(4.8)$ & 443 & 3.08 & agree \\
\hline $\begin{array}{l}\text { planting time of crops now unpredictable } \\
\text { generally }(n=145)\end{array}$ & $84(56.4)$ & $42(28.2)$ & $14(9.4)$ & $5(3.4)$ & 495 & 3.41 & agree \\
\hline $\begin{array}{l}\text { Fertilizer use increases the negative } \\
\text { effect of climate change }(n=144)\end{array}$ & $40(27.6)$ & $42(29.0)$ & $37(25.5)$ & $25(17.2)$ & 385 & 2.67 & agree \\
\hline Increases frequency of drought $(n=146)$ & $67(45.3)$ & $52(35.4)$ & $14(9.5)$ & $13(8.8)$ & 465 & 3.18 & agree \\
\hline $\begin{array}{l}\text { Increases frequency of flooding } \\
(n=145)\end{array}$ & $52(35.4)$ & $41(27.9)$ & $35(23.8)$ & $17(11.6)$ & 418 & 2.88 & agree \\
\hline $\begin{array}{l}\text { Increases effect of heat stress on on } \\
\text { livestock }(n=148)\end{array}$ & $71(47.3)$ & $60(4.0)$ & $8(5.3)$ & $9(6.0)$ & 489 & 3.30 & agree \\
\hline $\begin{array}{l}\text { Increases effect of heat stress on crops } \\
(n=146)\end{array}$ & $80(53.3)$ & $54(37)$ & $3(2.1)$ & $9(6.2)$ & 497 & 3.40 & agree \\
\hline $\begin{array}{l}\text { Increases effect of heat stress on farmers } \\
(n=146)\end{array}$ & $85(58.2)$ & $51(34.9)$ & $4(2.7)$ & $6(4.1)$ & 507 & 3.47 & agree \\
\hline $\begin{array}{l}\text { Increases poverty rate of farmers } \\
\text { generally }(n=146)\end{array}$ & $89(61.0)$ & $53(36.3)$ & $3(2.1)$ & $1(0.7)$ & 522 & 3.58 & agree \\
\hline $\begin{array}{l}\text { Increases pest and disease incidence in } \\
\text { crops }(n=145)\end{array}$ & $65(44.8)$ & $76(0.4)$ & $2(1.4)$ & $2(1.4)$ & 502 & 3.41 & agree \\
\hline $\begin{array}{l}\text { Increases pest and disease incidence in } \\
\text { livestock }(n=148)\end{array}$ & $64(43.2)$ & $71(48)$ & $5(3.4)$ & $8(5.4)$ & 487 & 3.29 & agree \\
\hline Inceases cost of crop production $(n=148)$ & $73(49.3)$ & $52(35.1)$ & $14(9.5)$ & $9(6.1)$ & 485 & 3.28 & agree \\
\hline $\begin{array}{l}\text { Increase in loss of agricultural land due to } \\
\text { erosion }(n=147)\end{array}$ & $43(29.3)$ & $59(40.1)$ & $28(19)$ & $17(11.6)$ & 422 & 2.87 & agree \\
\hline Reduction of soil fertility $(n=140)$ & $62(43.4)$ & $45(31.5)$ & $26(18.2)$ & $7(4.9)$ & 442 & 3.16 & agree \\
\hline $\begin{array}{l}\text { Increase in poverty level of farmers } \\
(n=144)\end{array}$ & $63(43.8)$ & $40(27.8)$ & $25(17.4)$ & $16(11.1)$ & 438 & 3.04 & agree \\
\hline $\begin{array}{l}\text { Increase in weed infestation of crops } \\
(n=143)\end{array}$ & $36(25.2)$ & $35(24.5)$ & $62(43.4)$ & $10(7.0)$ & 391 & 2.68 & agree \\
\hline Reduction in vegetational cover $(n=145)$ & $53(36.3)$ & $55(37.7)$ & $25(17.2)$ & $12(8.3)$ & 439 & 3.03 & agree \\
\hline $\begin{array}{l}\text { Reduction in family income generally } \\
(n=145)\end{array}$ & $47(32.4)$ & $44(30.3)$ & $35(24.1)$ & $19(13.1)$ & 409 & 2.82 & agree \\
\hline $\begin{array}{l}\text { Increase in family incomegenerally } \\
(\mathrm{n}=146)\end{array}$ & $22(15.1)$ & 31 (21.2) & $61(41.8)$ & 32 (21.9) & 335 & 2.29 & $\begin{array}{l}\text { Do not } \\
\text { agree }\end{array}$ \\
\hline $\begin{array}{l}\text { Increase in rate of sickness/infection } \\
(n=146)\end{array}$ & $51(34.9)$ & 54 (37) & $23(15.8)$ & $18(12.3)$ & 430 & 2.95 & agree \\
\hline $\begin{array}{l}\text { Decease in rate of sickness/ infection } \\
(\mathrm{n}=147)\end{array}$ & $20(13.6)$ & $16(10.9)$ & $76(51.7)$ & 35 (23.8) & 315 & 2.14 & $\begin{array}{l}\text { Do not } \\
\text { agree }\end{array}$ \\
\hline
\end{tabular}

${ }^{\star}$ Figures in parenthesis are percentages

\section{Strategies to Reduce/Alleviate the Effects of Climate Change}

Weighted scores (Table 3) show that respondents' favoured the planting of drought resistant/tolerant crop varieties, planting of many different types of crops (mixed-cropping) and planting of pest/disease resistant/tolerant crop varieties. Others included the rearing of heat tolerant livestock, planting of crops that can resist/tolerate flooding conditions and the adoption of agricultural insurance. The 
result in Table 3 also revealled that farmers agreed that mulching of crops to reduce water loss (3.33) and increase in use of organic manure (3.35) are coping strategies to reduce or alleviate the effect of climate change.

Table 3 : Coping Strategies to Reduce/Alleviate the Effect of Climate Change Possible strategy

\begin{tabular}{|c|c|c|c|c|c|c|c|}
\hline Possible strategy & 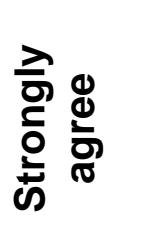 & $\frac{\Xi}{\frac{\$}{4}}$ & $\stackrel{\dot{\Phi}}{\frac{\mathbb{U}}{\sigma}}$ & 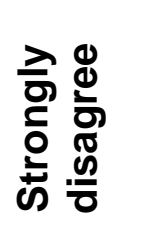 & 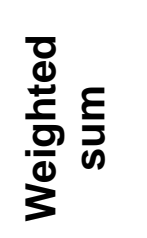 & 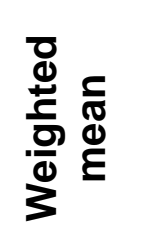 & 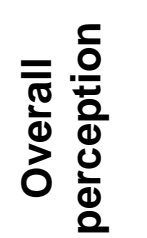 \\
\hline $\begin{array}{l}\text { Agricultural insurance of } \\
\text { enterprise (crop, livestock..) } \\
(n=146)\end{array}$ & $\begin{array}{c}81 \\
(55.5)\end{array}$ & $\begin{array}{c}51 \\
(34.9)\end{array}$ & $\begin{array}{c}4 \\
(2.7)\end{array}$ & $\begin{array}{c}10 \\
(6.8)\end{array}$ & 495 & 3.39 & agree \\
\hline $\begin{array}{l}\text { Planting of many different } \\
\text { types of crops (multi-crop } \\
\text { agriculture) }(\mathrm{n}=148)\end{array}$ & $\begin{array}{c}93 \\
(62.8)\end{array}$ & $\begin{array}{c}51 \\
(34.5)\end{array}$ & $\begin{array}{c}2 \\
(1.4)\end{array}$ & $\begin{array}{c}2 \\
(1.4)\end{array}$ & 531 & 3.59 & agree \\
\hline $\begin{array}{l}\text { Planting of drought } \\
\text { resistant/tolerant crop or } \\
\text { variety }(n=144\end{array}$ & $\begin{array}{c}103 \\
(71.5)\end{array}$ & $\begin{array}{c}36 \\
(25.0)\end{array}$ & $\begin{array}{c}3 \\
(25.0)\end{array}$ & $\begin{array}{c}2 \\
(1.4)\end{array}$ & 528 & 3.67 & agree \\
\hline $\begin{array}{l}\text { Planting of flood } \\
\text { resistant/tolerant crop or } \\
\text { variety }(n=146)\end{array}$ & $\begin{array}{l}7676 \\
(52.1)\end{array}$ & $\begin{array}{c}57 \\
(39.0)\end{array}$ & $\begin{array}{c}11 \\
(7.5)\end{array}$ & $\begin{array}{c}2 \\
(1.4)\end{array}$ & 499 & 3.42 & agree \\
\hline $\begin{array}{l}\text { Planting of pests and disease } \\
\text { resistant/tolerant crop or } \\
\text { variety }(n=149)\end{array}$ & $\begin{array}{c}94 \\
(63.1)\end{array}$ & $\begin{array}{c}40 \\
(26.8)\end{array}$ & $\begin{array}{c}14 \\
(9.4)\end{array}$ & $\begin{array}{c}1 \\
(0.7)\end{array}$ & 525 & 3.52 & agree \\
\hline $\begin{array}{l}\text { Rearing of heat tolerant } \\
\text { livestock }(n=149)\end{array}$ & $\begin{array}{c}83 \\
(55.7)\end{array}$ & $\begin{array}{c}59 \\
(39.6)\end{array}$ & $\begin{array}{c}5 \\
(3.4)\end{array}$ & $\begin{array}{c}2 \\
(1.3)\end{array}$ & 521 & 3.50 & agree \\
\hline $\begin{array}{l}\text { Mulching of crops to reduce } \\
\text { water loss }(n=146)\end{array}$ & $\begin{array}{c}74 \\
(97.3)\end{array}$ & $\begin{array}{c}49 \\
(32.7)\end{array}$ & $\begin{array}{c}20 \\
(13.3)\end{array}$ & $\begin{array}{c}3 \\
(2.1)\end{array}$ & 486 & 3.33 & agree \\
\hline $\begin{array}{l}\text { Increase in Use of organic } \\
\text { manure }(n=146)\end{array}$ & $\begin{array}{c}82 \\
(56.2)\end{array}$ & $\begin{array}{c}37 \\
(56.2)\end{array}$ & $\begin{array}{c}23 \\
15.8)\end{array}$ & $\begin{array}{c}4 \\
(2.7)\end{array}$ & 489 & 3.35 & agree \\
\hline $\begin{array}{l}\text { Stop the use of fertilizer }(n= \\
145)\end{array}$ & $\begin{array}{c}22 \\
(15.2)\end{array}$ & $\begin{array}{c}15 \\
(10.3)\end{array}$ & $\begin{array}{c}61 \\
(32.4)\end{array}$ & $\begin{array}{c}47 \\
(32.4)\end{array}$ & 302 & 2.08 & $\begin{array}{l}\text { Do not } \\
\text { agree }\end{array}$ \\
\hline
\end{tabular}

${ }^{*}$ Figures in parenthesis are percentages

\section{Sources of Information on Climate Change}

Table 4 shows that the main source of information on climate change was through personal experience (37.6\%), followed by radio (32.2\%) and extension agents $(19.5 \%)$. Climate change awareness through television $(6.7 \%)$ and fellow farmers $(4.0 \%)$ were only observed in the North East zone. Comparing sources of information awareness across the ecological zones, $40 \%$ in North West zone had radio as their main source, $60 \%$ in North East zone rely on personal expereince as a main source. The high percentage of farmers relying on personal experience might be due probably to the relatively hasher weather in the North East. In the Middle belt zone, $54 \%$ are aware of climate change mainly from extension agents. The most important information source on climate change was personal experience $(37.6 \%)$ 
followed by radio (32.2) and television (6.7\%). The farmers seems to have a thorough knowledge of the effect of climate change through personnal experience because their likelihood seems to be seriously threatened.

Table 4 : Sources of Awareness of Climate Change

$\begin{array}{lllll}\text { Sources } & \begin{array}{l}\text { North- } \\ \text { West }\end{array} & \text { MBZ } & \begin{array}{l}\text { North- } \\ \text { East }\end{array} & \text { Total } \\ \text { Extension Agent } & 1(2.0) & 27(54.0) & 1(2.0) & 29(19.5) \\ \text { Radio } & 40(81.6) & 2(4.0) & 6(12.0) & 48(32.2) \\ \text { Television } & 0(0) & 0(0) & 10(20) & 10(6.7) \\ \text { Personal experience } & 8(14.3) & 18(32.1) & 30(60) & 56(37.6) \\ \text { Fellow farmers } & 0(0) & 0(0) & 3(6.0) & 6(4.0)\end{array}$

${ }^{*}$ Figures in parenthesis are percentages

\section{Time When Farmers Started Noticing Effect of Climate Change}

Table 5 shows that majority $(45.8 \%)$ of the farmers started noticing the effect of climate change long time ago (6-10years) and about 39\% recently (5year and below). However, only $15.5 \%$ started noticing the effect very long time ago (above 10years). The Table also revealed that many (47.7\%) started noticing the effect recently in North East zone and $56.3 \%$ in North West zone. In the Middle Belt zone, majority (82\%) started noticing the effect long time ago. This diifferences in time of noticing effect of climate change might be attributed differences that exist between the communities.

Table 5 : Noticed time of Effect of Climate Change

\begin{tabular}{|c|c|c|c|c|}
\hline Time & $\begin{array}{l}\text { North- } \\
\text { West }\end{array}$ & MBZ & $\begin{array}{l}\text { North- } \\
\text { East }\end{array}$ & Total \\
\hline Recently (5 years \& below) & $27(56.3)$ & $7(14.0)$ & $\begin{array}{l}21 \\
(47.7)\end{array}$ & $55(38.7)$ \\
\hline Long time ago (6-10 years) & $13(27.1)$ & $41(82.0)$ & $\begin{array}{l}11 \\
(25.0)\end{array}$ & $65(45.8)$ \\
\hline $\begin{array}{l}\text { Very long time (above } \\
\text { 10years) }\end{array}$ & $8(16.7)$ & $2(4.0)$ & $\begin{array}{l}12 \\
(27.3)\end{array}$ & $22(15.5)$ \\
\hline
\end{tabular}

${ }^{*}$ Figures in parenthesis are percentages

\section{Relationship of the Perception of Climate Change with other Independent Variables}

As shown in Table 6, chi-square test was employed to determine relationship between farmers' climate change perception and other variables (since variables were mainly measured at nominal and ordinal levels). 
Table 6: Contingency Table of relationship between Perception of Climate Change and significant independent variables

\begin{tabular}{lcc} 
variables & \multicolumn{2}{c}{ Perception of climate change } \\
& low & high \\
\hline Agro-ecological zones & & \\
Middle-Belt & 70.0 & 30.0 \\
North-West & 42.0 & 58.0 \\
North-East & 22.0 & 78.0 \\
Age & & \\
Young & 32.5 & 67.5 \\
Middle aged & 53.7 & 46.3 \\
old & 35.7 & 64.3 \\
Educational level & & \\
Low & 37.7 & 62.3 \\
High & 61.0 & 39.0 \\
Coping strategy & & \\
Low & 66.2 & 33.8 \\
High & 26.8 & 73.2 \\
Communities & & \\
Nwogi (EM)-MB & 92.0 & 8.0 \\
Gbakogi kasara (NEM)-MB & 48.0 & 52.0 \\
Nasara-buhari (EM)-NW & 28.0 & 72.0 \\
Hayan-gada (NEM)-NW & 56.0 & 44.0 \\
Shawari (EM)-NE & 20.0 & 80.0 \\
Aldawari (NEM)-NE & 24.0 & 76.0 \\
\hline EM=extension model communities; NEM=none extension model communities &
\end{tabular}

Relationship of perception of climate change and other independent variables

The result of chi-square analysis in Table 7 indicate that there was a positive and significant relationship between perception of climate change and the following variables namely : agro-ecology $\left(X^{2}=23.52 ; p<0.05\right)$, age $\left(X^{2}=5.98 ; p<0.05\right)$, educational level $\left(X^{2}=6.47 ; p<0.05\right)$, level of strategy adopted for reducing climate change $\left(X^{2}=23.29 ; p<0.05\right)$ and communities of residence $\left(X^{2}=37.36 ; p<0.05\right)$.

On the other hand, respondents' number of wives $\left(X^{2}=4.29 ; p>0.05\right)$, number of children $\left(X^{2}=1.45 ; p>0.05\right)$, household size $\left(X^{2}=0.61 ; p>0.05\right)$, farm size $\left(X^{2}=1.47\right.$; $p>0.05)$, farming experience $\left(X^{2}=0.07 ; p>0.05\right)$ and information awareness source $\left(X^{2}=2.52 ; p>0.05\right)$ were found to be positive but not significant relationship to perception of climate change.

The variation of the impact of climate change across agro-ecological zones is most likely to be the reason for the positive and significant relationship to farmers' perception due to the fact that they perceive climate change based on its manifestation in their environment. This will equally apply for different communities. For educational level, as indicated in the contingency table in Table 6 , the higher the level, the more a respondent is likely to perceive climate change to be a significant problem in the area. Also, the age of farmers has an influence on their perception of climate change. The much older farmers are likely to have perceived climate change 
based on the generational changes they have witnessed within their environment over time.

Table 7 :Chi-square Table of Relationship of perception of climate change and other independent variables

\begin{tabular}{llcccc}
\hline s/no & Variables & $\mathbf{X}^{2}$ & DF & $\begin{array}{c}\text { Contingency } \\
\text { coefficient }\end{array}$ & $\begin{array}{c}\% \text { level of } \\
\text { significance }\end{array}$ \\
\hline 1 & Agro-ecological & 23.52 & 2 & $0.37^{*}$ & 0.000 \\
& zones & & & & \\
2 & Number of wives & 4.29 & 2 & 0.18 & 0.117 \\
3 & Age & 5.98 & 2 & $0.20^{*}$ & 0.050 \\
4 & Number of children & 1.45 & 2 & 0.10 & 0.485 \\
5 & House hold size & 0.61 & 2 & 0.07 & 0.739 \\
6 & Educational level & 6.47 & 1 & $0.21^{*}$ & 0.009 \\
7 & Farm size & 1.47 & 2 & 0.10 & 0.479 \\
8 & Farming experience & 0.07 & 2 & 0.02 & 0.968 \\
9 & Reduction strategy & 23.29 & 1 & $0.37^{*}$ & 0.000 \\
10 & communities & 37.36 & 5 & $0.44^{*}$ & 0.000 \\
11 & Awareness source & 2.52 & 1 & 0.13 & 0.078 \\
\hline
\end{tabular}

*significant at $p<0.05$

Most farmers with low education had high perception of climate change because climate tends to impact more on their crop and livestock production efforts as this is probably the main livelihood sources. That is, farmers livelihood depends on agriculture and any distortion in its production chain can be responsible for the high farmers perception of effect of climate change. On the other hand, farmers with high educational level may record low perception due to the fact that they may have other sources of income other than farming

\section{Conclusion and Recommendation}

Farmers are fully aware of the effect of climate change and are also aware of the possible coping strategies such as the need for agricultural insurance, planting of drought and flood tolerant varieties and reduction of water loss through practices such as mulching and rearing of heat tolerant livestock. However, farmers did not perceive stoppage the of use of inorganic fertliser as a coping strategy. Any recommendation to stop the use of inorganic fertiliser will thus not be readily accepted by farmers. Efforts should be geared towards developing and making available crop varieties and livestock breeds that are tolerant to adverse conditions associated to climate change such as diseases, flood, drought and temperature. A multi-media enlightenment campagn of the effects and posssible coping strategies should be adopted by all tiers of government to reach the farmers using the available extension structures on ground. Also, farming communities can run local disaster risk committees to encourage local adaptation measures as survival tactics for the purpose of ensuring food security.

\section{References}

Awosika, L.F., French, G.T., Nicholls, R.T. and C.E. Ibe (1992). The Impacts of Sea level rise on the coastline of Nigeria. In: O'Callahan, J. (Ed.). Global Climate Change and the Rising challenge of the Sea. Proceedings of the 
IPCC Workshop at Margarita Island, Venezuela. 6-13 March, 1992. National Oceanic and Atmospheric Administration, Silver Spring, MD, USA. 960pp.

CTA (2009). Implication of Climate Change for sustainable agricultural production systems in ACP countries: Getting information and communication strategies right. A Compilation Document.

Deressa, T.T. and R.M. Hassan (2009). Economic Impact of Climate Change on Crop Production in Ethiopia: Evidence from cross-section measures. Journal of African Economies. Vol. 18(4) pp.529-554.

FAO (2009). Climate change in Africa: The threat to Agriculture. http://www.fao.org.africa. International Food Policy Research Institute (2009). Climate Change: Impact on Agriculture and costs of adaption. Online: http://www.ifpri.org/publication. 10th January, 2010.

Kurukulasuriya, P. and R. Mendelson (2007). Endogenous irrigation: The Impact of Climate Change on farmers in Africa. World Bank Policy Research Working Paper 4278.

Sambo, M.N (2010). Climate Change in Kaduna State. Paper presented at the second Lagos State Summit on Climate Change. 4th May 2010.

Watson, R.T., Zinyowera, M.C. and R.H. Moses (1997). The regional impacts of climate change: An assessment of vulnerability. A special report of IPCC Working Group II. Published for the International Panel on Climate Change. Online: http://www.ipcc.ch. 10th January, 2010 